\title{
INDIVIDUALISATION AND PROPORTIONING OF PHYSICAL LOAD DURING SPORTS CLASSES
}

\section{Summary \\ Introduction}

Often sports teachers proportion the same amount of load to all students irrespective of their physical training, physical and functional development. Relation between regulated and proportioned physical loads and moments of rest become the structural and methodological basis of sports classes.

\section{Aim of the Study}

Development of proportioned exercises in sports classes according to the indicators of every student's physical training, physical and functional development.

\section{Materials and Methods}

Testing, anthropometry, pulsometrics, mathematical statistics.

\section{Results}

Exercises with individualised proportion ofload were worked out for developing strength, coordination, stamina, flexibility, speed according to the indicators of functional and physical training in order to individualise the proportion of physical load. The assessment analysis of the efficiency of the set of exercises has been done.

\section{Conclusions}

Individualised and proportioned loads positively influence the indicators of the students' physical training and development of positive feelings.

Keywords: physical load, sports trainings, sports class.

\section{Introduction}

An appropriate portioning of physical load activates the physiological processes in students' organisms, stimulates adaptation skills and increases the functional reserves of the organism. Sedentary lifestyle or physical load that does not correspond to the student's physical abilities can lead to health problems and even negatively impact parameters of individual physical and functional development (Jansone, Krauksts, 2005).

Research shows that often sports teachers proportion the same amount of load to all students irrespective of their physical training, physical and functional development (Hardman, Marshall, 2000). If physical load and intensity during sports classes is the same for all students, there is a possibility to negatively impact the parameters of health of several individuals (Patte, Shepard, 1989). When the teacher chooses a load, it has to be proportioned differently for weaker and stronger students as an individualised approach will help to adapt to biological changes in the organism more successfully; it will also help to have fun from physical activities increasing their competitiveness in the conditions of the market economy (Malina, 1996).

Relation between regulated and proportioned physical loads and moments of rest become the structural and methodological basis of sports classes. Depending on the physical condition and training of every student, one and the same exercise to be done during a sports class will be perceived as a different physical load leading to various counter-actions in the students' organisms. Thus, the 
load is not the content and volume of the exercise to be done but the results and consequences of it that depend on the psycho-physiological potential of the organism (Bouchard, Shepard, 1994). Load can be divided into two groups: external load characterised by volume and intensity and internal load influencing the physiological and psychological condition of the entire organism. If the load remains the same for a long period of time and the organism has got used to it, then during the recovery process after a load all functions of the organism return back to their starting condition. Through diversifying and proportioning as well as increasing the usual volume and intensity of exercises, the functional abilities of the organism together with the developmental level of the physical abilities increase during the recovery process (Jansone, Krauksts, 2005). The volume and intensity of the load creates a certain dualistic interconnection: when intensity increases, the volume of how much load can be taken decreases. Therefore when working with 16 years old students one have to assess the maximum load and optimal load individually. The maximum load is a load that a student can take without negatively impacting his or her organism. An optimal load results in super compensation. A total sum of load in sports classes should be understood as an impact of the sum of separate exercises on the students' organism. To regulate the load individually means to ensure that there is an optimal relation between individual volume and intensity of exercises where the optimisation of volume depends on the proportioning of physical exercises, the methods applied, organisational forms used as well as the emotional background. The objective parameters showing the impact of load are: blood pressure, body temperature, maximum consumption of oxygen, pulse frequency, etc. According to the conclusions of Canadian universities, the efficiency of cooperation between a teacher and a student during a sports class increases if an individualised approach is used (Hardman, Marshall, 2000).

One of the tasks in sports classes is to attain the development of physical qualities. The do not develop in isolation from one another - exactly the opposite: they develop in close interaction. When one physical quality is being developed, there is a considerable impact on the rest. Physical development and training is a topical problem in scientific research in modern sports pedagogy as it forms not only the physical but also mental health of the human being. Regular physical activities are of a great significance in keeping fit and strengthening health in a long run. The results of the research show that the functions of inner organs slowly and gradually adapt to systematic loads. That is why sports teachers have to ensure a gradual increase of overall physical conditions that is achieved by individualising and proportioning exercises according to the parameters of every student's physical development, training and functional abilities.

\section{Aim of the Study}

To develop a set of proportioned exercises for sports classes according to the indicators of physical training, physical and functional development of 16 years old students.

\section{Materials and Methods}

The following methods were applied in the research: testing to state the parameters of the student physical condition, anthropometry to state the parameters of physical development, pulsometrics to state the functional abilities. Mathematical statistics.

- To assess the parameters of students' physical condition, it was set: push-ups $33 \pm 13$, hanging in bent arms $32.9 \pm 13.1 \mathrm{~s}$, sit-ups $27 \pm 3$ times, jumping from the place taking off with both feet $(8$ jumps) $17.43 \pm 2.40 \mathrm{~m}$, jumping from the place $212 \pm 24 \mathrm{~cm}$, shuttle run $3 \times 10 \mathrm{~m} 7.66 \pm 0.69$ $\mathrm{s}$, stamina run $1600 \mathrm{~m} 5.58 \pm 2.35 \mathrm{~min}, 30 \mathrm{~m}$ run $4.52 \pm 1.05$, jumping with the skipping rope with both feet $72 \pm 25$ times.

Having analyzed the obtained results it can be concluded that the 16 years old students have a very different physical condition. 
- While evaluating the parameters of the physical development, the following average results have been obtained: age 16 years, height $174 \pm 7 \mathrm{~cm}$, weight $62.4 \pm 13.5 \mathrm{~kg}$, waist circumference $79 \pm$ $9 \mathrm{~cm}$, wrist $17 \pm 1 \mathrm{~cm}$, right hand strength $33 \pm 9 \mathrm{~kg}$, left hand strength $31 \pm 8 \mathrm{~kg}$, arm length 77 $\pm 3 \mathrm{~cm}$, leg length $105 \pm 5 \mathrm{~cm}$.

Having evaluated the parameters of the physical development it can be concluded that they are irregular, and that can be explained by the peculiarities characteristic to the age.

- The parameters of the functional condition were evaluated by stating: heart frequency from the lying position $81 \pm 8$ beats/min, heart frequency from the sitting position $85 \pm 9$ beats/min, heart frequency from the standing position $87 \pm 13$ beats/min, heart frequency after the load $95 \pm 13$ beats/min P3, heart frequency after the load $141 \pm 18$ beats/min P1, after the load $114 \pm 16$ beats/ min P2, the systolic blood pressure $114 \pm 16 \mathrm{~mm} / \mathrm{Hg}$, diastolic blood pressure $71 \pm 9 \mathrm{~mm} / \mathrm{Hg}$, breath holding at inhalation $0.35 \pm 0.09 \mathrm{~s}$, breath holding at exhalation $0.16 \pm 0.06 \mathrm{~s}$.

There are differences in practically all functional condition parameters. Especially vivid they are during the recovering process after the load. Two student groups had been formed after obtaining of the background data.

- Exercises with individualised proportion of load were worked out during the research for developing strength, coordination, stamina, flexibility and speed qualities. The exercises were applied according to the worked-out physical quality expressions form development plan with an individualized dosage for the students having different parameters of physical condition, physical and functional development (Table 1).

Table 1. Individualised plan for developing the expression of physical qualities for 16 years old

\begin{tabular}{|c|c|c|}
\hline Month, week & $\begin{array}{l}\text { The developmental tasks of the form } \\
\text { of expression of physical qualities }\end{array}$ & Content, volume, proportion of exercises \\
\hline \begin{tabular}{|l|} 
January \\
Week 1
\end{tabular} & $\begin{array}{l}\text { 1. To develop overall strength for arm } \\
\text { muscles } \\
\text { 2. To develop overall strength for back } \\
\text { muscles }\end{array}$ & $\begin{array}{l}\text { 1. Bent arms, straightening push-ups } \\
\text { a) } 2 \times 20 \mathrm{r} \text {; b) } 2 \times 15 \mathrm{r} \\
\text { 2. Bending, lifting of arms and legs } \\
\text { a) } 3 \times 16 \mathrm{r} \text {; b) } 3 \times 10 \mathrm{r}\end{array}$ \\
\hline Week 2 & $\begin{array}{l}\text { 1. To develop strength stamina } \\
\text { 2. To develop speed stamina }\end{array}$ & $\begin{array}{l}\text { 1. To move in deep squatting, squats } \\
\text { a) } 3 \times 20 \mathrm{~m} \text {; b) } 3 \times 15 \mathrm{~m} \\
\text { a) } 3 \times 20 \mathrm{r} \text {; b) } 3 \times 15 \mathrm{r} \\
\text { 2. Run } \\
\text { a) } 3 \times 200 \mathrm{~m} \text {; b) } 2 \times 200 \mathrm{~m}\end{array}$ \\
\hline \begin{tabular}{|l|} 
March \\
Week 8
\end{tabular} & $\begin{array}{l}\text { 1. To develop overall stamina } \\
\text { 2. To develop speed stamina }\end{array}$ & $\begin{array}{l}\text { 1. Run } \\
\text { a) } 1 \times 2000 \mathrm{~m} \text {; b) } 1 \times 1500 \mathrm{~m} \\
\text { 2. Carrying of a sand ball } \\
\text { a) } 5 \times 25 \mathrm{~m} \text {; b) } 4 \times 25 \mathrm{~m}\end{array}$ \\
\hline Week 10 & $\begin{array}{l}\text { 1. To develop reaction to motion speed } \\
\text { 2. To develop strength stamina }\end{array}$ & $\begin{array}{l}\text { 1. To start a run from various initial positions (from laying } \\
\text { on the stomach; from laying on the back; after turning a } \\
\text { somersault). a) } 3 \times 3 \mathrm{r} \text {; b) } 3 \times 2 \mathrm{r} \\
2 \text {. To move in squats holding onto the ankles, transferring } \\
\text { body weight from one leg to the other } \\
\text { a) } 3 \times 20 \mathrm{~m} \text {; b) } 3 \times 15 \mathrm{~m}\end{array}$ \\
\hline \begin{tabular}{|l|} 
April \\
Week 13
\end{tabular} & $\begin{array}{l}\text { 1. To develop coordination } \\
\text { 2. To develop overall stamina }\end{array}$ & $\begin{array}{l}\text { 1. A ball is rolling on the floor, the student must catch up } \\
\text { and jump over it } \\
\text { a) } 4 \mathrm{r} \text {; b) } 3 \mathrm{r} \\
\text { 2. Slow run for } 6 \mathrm{~min}\end{array}$ \\
\hline Week 14 & $\begin{array}{l}\text { 1. To develop speed stamina } \\
\text { 2. To develop strength stamina }\end{array}$ & $\begin{array}{l}\text { 1. Speed increase } \\
\text { a) } 5 \mathrm{r} \text {; b) } 3 \mathrm{r} \\
\text { 2. Squats, jumps with a skipping-rope } \\
\text { a) } 3 \times 20 \mathrm{r} \text {; b) } 3 \times 15 \mathrm{r} \\
\text { a) } 3 \times 1 \mathrm{~min} \text {; b) } 2 \times 1 \mathrm{~min}\end{array}$ \\
\hline
\end{tabular}




\section{Results and Discussion}

To assess the set of exercise and the efficiency of the impact a particular portion on the parameters of physical condition of a 16 years old student, the parameters in following disciplines were compared in December and May: stamina run $1600 \mathrm{~m} ; 30 \mathrm{~m}$ run; push-ups from laying on the back on the ground; throwing of a ball with a running start; jumping from the place.

Having evaluated the influence of the physical exercise routine on the student physical condition while individualising and setting a definite proportion of load, we obtained the following results:

- In the stamina run $1600 \mathrm{~m}$ (s) the results have not improved. In May the results in this exercise increased for 5 students from the 1 st group and for 3 students from the 2 nd group. Decreased for 4 students from $1^{\text {st }}$ group and 6 from $2^{\text {nd }}$ group. The result has not changed for 1 student from the 2nd group. The average increase is $10.89 \mathrm{~s}$, but it is not statistically significant. The average parameter in December was 403.89 s, but in May - 414.78 s. The standard deviation has increased from $\pm 38.56 \mathrm{~s}$ up to $\pm 59.50 \mathrm{~s}$. The variation coefficient in the beginning was 9.5 , but in May -14 .

Table 2. Results of stamina run for 16 years old students. (s)

\begin{tabular}{|l|l|l|}
\hline Stamina run 1600 m & Group 1 & Group 2 \\
\hline Average & 403,89 & 414,78 \\
\hline Standard deviation & 38,56 & 59,50 \\
\hline Variation coefficient & $9,5 \%$ & $14,3 \%$ \\
\hline Average increase & & 10,89 \\
\hline Empirical value of the Student's criterion & & 1,31 \\
\hline Theoretical value of the Student's criterion & & 2,11 \\
\hline Increase is not likely. & & \\
\hline
\end{tabular}

- In 30 m run (s) the results have improved. Comparing the results in December and May, in May higher results were shown by the 7 students from the 1st group and 9 students from the 2nd group. Lower results were shown by 2 students from the 1st group and 1 student from the 2nd group. The average increase is $0.23 \mathrm{~s}$, it is statistically significant. The average parameter in December was $4.72 \mathrm{~s}$, but in May it improved and was $4.49 \mathrm{~s}$. The standard deviation was $\pm 0.30 \mathrm{~s}$ in December, but in May $\pm 0.19 \mathrm{~s}$ showing less dispersion of the results. The variation coefficient has changed from 6.3 , up to 4.2 .

Table 3. Results of $30 \mathrm{~m}$ run for 16 years old students. (s)

\begin{tabular}{|l|l|l|}
\hline $\mathbf{3 0}$ m run & Group 1 & Group 2 \\
\hline Average & 4,72 & 4,49 \\
\hline Standard deviation & 0,30 & 0,19 \\
\hline Variation coefficient & $6,3 \%$ & $4,2 \%$ \\
\hline Average increase & & $-0,23$ \\
\hline Empirical value of the Wilcocson's criterion & & 7,0 \\
\hline Theoretical value of the Wilcocson's criterion & & 40,0 \\
\hline Increase is likely. & & \\
\hline
\end{tabular}


- In sit-ups (times) comparing the results in December and May it is seen that the results have significantly improved in both groups. The average increase is 36 times. It is statistically significant as the probability of a mistake is $<0.05$. In December the average result in the class was 27.1 time,

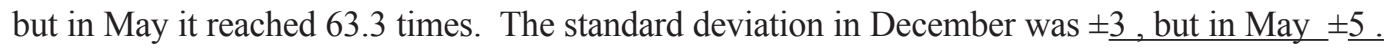
The variation coefficient in December was 9.6, but in May - 7.7.

Table 4. Results of sit-ups for 16 years old students (times).

\begin{tabular}{|l|l|l|}
\hline Sit-ups & Group 1 & Group 2 \\
\hline Average & 27,1 & 63,3 \\
\hline Standard deviation & 3 & 5 \\
\hline Variation coefficient & $9,6 \%$ & $7,7 \%$ \\
\hline Average increase & & 36 \\
\hline Empirical value of the Wilcocson's criterion & & 0,0 \\
\hline Theoretical value of the Wilcocson's criterion & & 40,5 \\
\hline Increase is likely. Probability of a mistake $<0.05$ & & \\
\hline
\end{tabular}

- Ball throwing with the approach (m). This event was done only in May, therefore we cannot compare it (Figure 1). The highest result in the class was $60 \mathrm{~m}$, the lowest $-25 \mathrm{~m}$. 5 students were free from the execution of this event. The average result is $49 \mathrm{~m}$. The dispersion around the average result is big, as the standard deviation is $\pm 10 \mathrm{~m}$. The results are not homogeneous, that we can see from the highest and lowest result, as well as the variation coefficient which is $21.01(\mathrm{~S} \%>10)$.

Figure 1. Results of ball throwing with the approach.

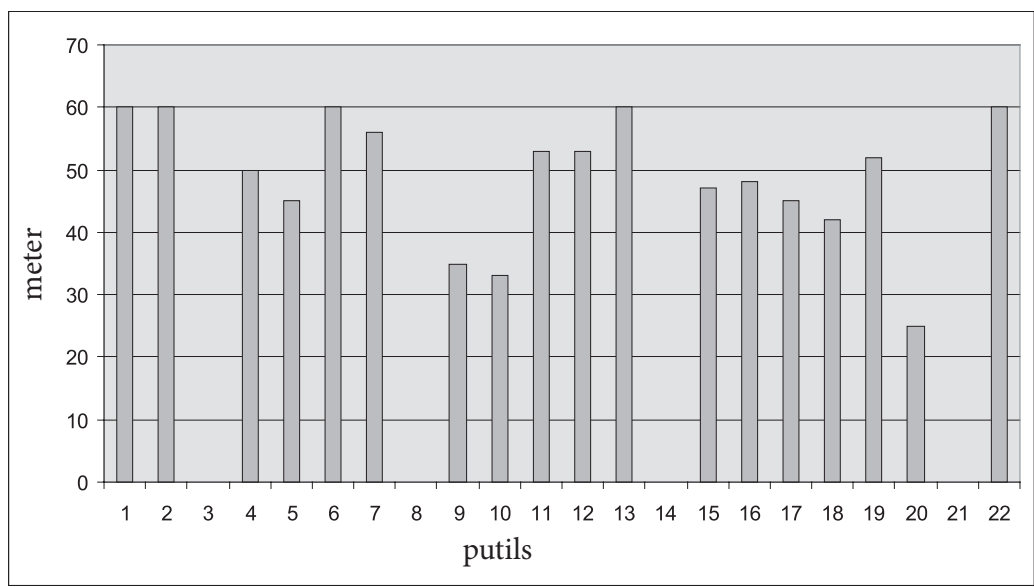

- In jumping from the place $(\mathrm{cm})$ the results have improved. Higher results were shown by 5 students from the 1st group and 6 students from the 2nd group when the results in December and May were compared. The results have no changed for 2 students from the 1 st group. Lower results were shown by 2 students from the 1 st group than they had been in December. Lower results were shown by 3 students from the 2 nd group in May. The average increase is $5 \mathrm{~cm}$. It is statistically significant as the probability of a mistake is $<0.05$. In December the average result was $217 \mathrm{~cm}$, but in May - $221 \mathrm{~cm}$. The standard deviation in December was $\pm 21 \mathrm{~cm}$, but in May $- \pm 17 \mathrm{~cm}$. The variation coefficient in December was 9.5, but in May -7.8 (Table 5). 
Table 5. Results in jumping from the place (cm).

\begin{tabular}{|l|l|l|}
\hline Jumping from the place & Group 1 & Group 2 \\
\hline Average & 217 & 221 \\
\hline Standard deviation & 21 & 17 \\
\hline Variation coefficient & $9,5 \%$ & $7,8 \%$ \\
\hline Average increase & & 5 \\
\hline Empirical value of the Wilcocson's criterion & & 5,5 \\
\hline Theoretical value of the Wilcocson's criterion & & 6,0 \\
\hline Increase is likely. Probability of a mistake $<0.05$ & & \\
\hline
\end{tabular}

\section{Conclusions}

- Having analyzed the obtained results it can be concluded that the 16 years old students have a very different physical condition. Having evaluated the parameters of the physical development it can be concluded that they are irregular, and that can be explained by the peculiarities characteristic to the age. There are differences in practically all functional condition parameters. Especially vivid they are during the recovering process after the load. Two student groups had been formed after obtaining of the background data.

- As a result of the research, five sets of exercises were worked for developing strength, coordination, stamina, flexibility and speed qualities. The exercises were applied according to the worked-out physical quality expressions form development plan with an individualized dosage for the students having different parameters of physical condition, physical and functional development.

- Thus it can be concluded that an individualized load dosage influenced positively the college student parameters of physical condition, it facilitated the improvement in health and development of a positive well-being.

- Physical development and training is a topical problem in scientific research in modern sports pedagogy as it forms not only the physical but also mental health of the human being.

\section{REFERENCES}

1. Bouchard L., Shepard R. J. (1994) Physical Activity, Fitness and Helth: the Model of Keykoncepts in International Proceedings and Lousensus. Champaign, IL: Human Kinetics. p. 77-88.

2. Hardman K., Marshall J. (2000) The State and Status of Physical Education in Schools in International context. European Physical Education Review (6), p. 203-229.

3. Jansone R., Krauksts V. (2005) Sporta izglītības didaktika skolā. Rīga: RaKa, 336 lpp.

4. Malina R. M. (1996) Tracking of Pysical Activity and Physical Fitness Across the Lifespan. Research Quatesly of Exercise and Sports (67), p. 48-57.

5. Patte R. R., Shepard R. (1989) Characterics of physical Fitness in Youth in perspectives. Exercise and Sports Medicine (2), p. 1-43.

Associate Professor Mg. psych., Mg. paed. Žermēna Vazne Latvian Academy of Sport Education

Address: Brīvības iela 333, Rīga,

LV-1006, Latvia

Phone: +37167543430

Fax: +371 67543480

E-mail: z.vazne@,e-teliamtc.lv
Professor Dr. paed. Rasma Jansone

Latvian Academcy of Sport Education

Address: Brīvības iela 333, Rīga,

LV-1006, Latvia

Phone: +371 67543430

Fax: +371 67543480

E-mail: Rasma.Jansone@1spa.lv 